\title{
The Visual Co-textualization of Spatio-Joual in the Motel Galactic Series
}

\author{
Charlotte Pylyser, Université KU Leuven \\ Gabriel Tremblay-Gaudette, Université du Québec à Montréal
}

Not unlike the small Gallic village surrounded by the Roman troops in Goscinny and Uderzo's famous Astérix series, Quebec remains a Francophone enclave in an overwhelmingly English-speaking environment. As is commonly known, the province, which was first discovered in 1534 by a French explorer and settled in 1608 by Samuel de Champlain, differs from the remaining nine Canadian provinces and three territories (and indeed from most of North America) based on its linguistic and cultural particularity. Language is the defining trait at the heart of Quebec's cultural and folkloric production, and this fact is shown prominently in its comics history ${ }^{1}$.

As contextualized by Véronneau and Viau, the first period of the history of Quebecois comics, which ran from 1904 until 1910, was marked by the mass introduction of comic strips into newspapers. This immensely prolific era was characterized notably by a heavy reliance on the popular language of rural citizens moving en masse to the city. Commonly referred to as Joual, a peculiar pronunciation of the word $\mathrm{cheval}^{2}$, this Quebecois form of French language could be observed in the comics of pioneers such as

\footnotetext{
${ }^{1}$ It should be pointed out that even though the province of Quebec is primarily Frenchspeaking, it also houses a smaller English-speaking population. The 2006 official census of Quebec shows that in a population of slightly less than 8000000 inhabitants, $78,9 \%$ speaks French as a native language, 8,3\% speaks English and 12,8\% speaks Other. The Anglophone and allophone population is mostly located in Montreal, the province's largest city (Secrétariat à la politique linguistique Québec). It should also be noted that there are Francophone communities in other Canadian provinces, which only adds to the complex and at times explosive linguistic, cultural and political relationships in federal Canada.

${ }^{2}$ It is important to note that the term Joual is the object of a polemic between linguists and intellectuals. This polemic came to a head during the Quiet Revolution, when writers, songwriters and playwrights such as Michel Tremblay, Réjean Ducharme, and Robert Charlebois, to name only a few, relied heavily on the sociolect. Some deemed it a bastardized, ugly derivation of International French and believed that Quebec's society should seek to emulate the latter; others claimed instead that using Joual was a means to put forward Quebec's cultural specificity and national pride or simply wanted to write in a language that they considered their own; still others contested the use of Joual as a general term to designate all of Quebec's dialectal French as the term primarily refers to the dialect of Montreal. While we acknowledge that there is a tremendous variety of dialects within the Canadian francophony and that, from a linguistic point of view, each requires a separate term to be identified with, considering the scope of this paper we will henceforth use "Joual" to describe the general Quebecois French sociolect as opposed to standard page
} 
Albéric Bourgeois, Raoul Barré and Joseph Charlebois, who used it as a means to "speak to the readership" in their own language. Later, during the countercultural movement of the 1960s and1970s, Joual was once again highly visible in Quebecois comics. In a period that came to be known as the Printemps de la bande dessinée québécoise ${ }^{3}$, a new generation of cartoonists emerged who revitalized the Quebecois comics scene with their publications in the many fanzines and magazines that technological evolutions and shifts in publication culture had made possible. This time around, Joual was not employed in order to accommodate a readership, however, but rather as an ideological statement and action, as Pierre Rambaud explains in the mission statement of Magazine BD: "[Joual est] un besoin bien naturel [...]: lire, voir, regarder, écouter, toucher, c't'Hostie de Kébec, sans intermédiaires. Se lire, se voir, se regarder, se toucher, s'écouter, se rire ou se pleurer, mais en tout cas, se faire soi-même, se respecter et se faire respecter... Et bien, croyez-le ou non, c'est parti de tout ça BD!" (Rambaud, in Carpentier, 64, 1974). Rambaud's statements are of course also to be understood in the larger context of the so-called Quiet Revolution of the 1960s in which Quebecois society was secularized and important corporations were nationalized to great social and economic success. This revolution (or evolution) fuelled Quebecois nationalist sentiments and soon the protection of the Quebecois language and culture and even the independence of Quebec from Canada became important political themes. The struggle for sovereignty is one that is still ongoing for a part of the voting public in Quebec and language is still an important theme in this effort, but in this paper we emphatically look at Joual from the point of view of folklore rather than ideology, which entails a focus on the micro-level of the text and its intertext rather than on the linguistic, cultural and political Canadian macro-level.

The contemporary Quebecois comics scene is, amongst other things, also known for its use of Joual, but this time around works published in La belle province are not read solely by its own inhabitants. Jimmy Beaulieu's critically acclaimed Comédie Sentimentale Pornographique (2011), for example, was released under the Shampooing imprint of the important French publisher Delcourt and has been reprinted several times. Michel Rabagliati's album Paul à Québec (2009) has similarly won numerous prizes, including the prestigious Public's Choice Award at the 2010 Festival international de la bande dessinée d'Angoulême. Since both books contain dialogue relying partly on Joual, the fact that these works were successful overseas indicates that the "language barrier" constituted by Joual is perhaps not as insurmountable as what is commonly thought of, or perhaps that Quebecois comics can succeed not despite their linguistic particularities, but rather because of them. The evolution which makes Quebecois comics available to audiences which are not proficient in Joual

3 According to Lemay, this period ranges from 1968 to 1975. 
invites a number of questions with regard to the way in which comics can make language accessible to the reader. One wonders whether it is the copresence of words and pictures specific to the comics medium that creates possibilities for comprehension. And if so, in what way exactly the interaction of words and pictures can generate (linguistic) intelligibility. Finally, this text raises the question as to how the intelligibility-generating operations possible in the comics medium can be used as creative narrative devices on a micro and a macro-level.

A panel from La famille Citrouillard, a 1907 comic strip by René-Charles Béliveau featuring a family of farmers recently installed in Montreal, can serve as an introduction to the intelligibility problematic. In this strip, the family experiences the wonder of using a gas-powered oven for the first time: the second panel, reproduced below (Image 1), shows the mother asking her son to go fetch some matches to light the oven:



Image 1 
A reader unfamiliar with Old Joual might not be able to understand the request to go fetch matches, which the mother makes to her son, simply by reading the sentence "Cours cri des alumettes au coin, Gugusse", as "cri" usually means "scream", and not "aller chercher". However, in this case, "cri" is actually an abbreviation of the verb "quérir (aller chercher)". The reader may (partially) infer the latter meaning because he can see the small boy running past the edge of the panel. Thus, it is the combination of the textual statement and the visual information that can allow a reader to deduct the meaning of this obscure, forgotten Joual term.

This paper aims to explore the phenomenon described in the previous paragraph which we propose to call "visual co-textualization" rather than visual contextualization after the difference which contemporary linguistics makes between the extra-textual environment of a given utterance (context) and its textual or visual surroundings (co-text). It should be noted, however, that in the fields of reading comprehension and cognition studies, the term contextualization is used to designate the set of reading strategies which we will engage with in this text. We will first offer a brief consideration on the matter of comics' hybridity before outlining a conceptual framework for visual co-textualization, after which we will proceed to the analysis of the Motel Galactic trilogy (2011-2013), a series of Quebecois science-fiction comics written primarily in Joual and produced by the tandem Francis Desharnais (scenario) and Pierre Bouchard (drawings). Our analysis will focus primarily on the first two books of the trilogy.

\section{Visual Co-textualization and Non-standard Language in Comics}

\subsection{The Word/Picture Question in Comics Studies}

If we are to approximate the concept of the visual co-textualization of language in comics, it is of course important to pay some attention to the form's doubleness in terms of verbal and visual interaction. This question has been investigated numerous times by comics scholars in the young academic history of the form and often seems to create tension with regard to how we ought to conceive of the medium, a problem which is amplified in the debates surrounding the graphic novel (see Varnum and Gibbons; Tremblay-Gaudette 2011; Pylyser). One of the main points of contention in the definitional project of comics is whether an object intrinsically requires the presence of both words and pictures in order to function as a comic. With regard to the word/picture question, a division has been established between those scholars who believe that comics must involve text and pictures at all times (see Töpffer (quoted in Peeters, 105, 1998), Harvey ("Comedy at the Juncture of Word and Image", 75, in Varnum and Gibbons 2001), Hatfield (2004), Marion; Pernin; and Morgan, we may call 
this group the "iconotextualists") and those who consider text not to be a fundamental formal component of the medium, but believe pictures to be essential (see Couperie; Groensteen; and McCloud), we may call this group the "pictorialists" ${ }^{4}$. Thirdly, a variant on the iconotextualist position has emerged. In this variant, it is not required for a comic book to contain both visual and verbal signs, but it is maintained that comics never truly function in either an exclusively verbal or an exclusively visual mode. As Jan Baetens explains in his article on "Words and Images" for the Cambridge Companion to Comics (forthcoming, 2016), even in wordless comics that contain neither captions nor speech balloons, the verbal component is usually present in the paratext (for example the title) of the comic book. Baetens also emphasizes the semiotic finding that "the reading of visual signs is never limited to the strictly visual realm." Indeed, verbal cognitive processes are an inextricable part of a receptor's interpretation of pictures because we must name what we perceive. In keeping with these considerations we can thus supplement the already widely accepted notion that a word/text in a comic book also always has a minimal visual character (which Lapacherie has called a text's grammatextuality) with the notion that a picture also has a verbal reverberation. While it is decidedly not our ambition to solve the definitional challenges of the comics medium in this text, we do want to draw attention to the third voice in this debate since it problematizes the dichotomy between word and image as it underlies the definition of both the iconotextualists and the pictorialists. In doing so, it testifies to the complexity of the verbal-visual interplay in comics, which is of course what we will engage with in our analysis of Motel Galactic.

\subsection{Visual Co-textualization of Language in Comics, Theoretical Contexts}

In terms of theory, the visual co-textualization of language in comics proves to be a highly elusive concept. While it has been touched upon by a variety of disciplines, none of them provide immediately useful perspectives for the analysis of the Motel Galactic series which we seek to present in this text. As a way of developing a framework for visual cotextualization that suits our endeavour, we propose a contrasting exercise involving investigations, findings and points of interest from comics studies, education theory, reading comprehension and cognition studies as well as cultural studies.

Comics studies, the discipline into which this text inscribes itself most fully, focuses primarily on the element which has been introduced in the previous section: the unique features of the comics language, embodied

\footnotetext{
${ }^{4}$ A more in-depth discussion of the debate about the definition of comics between these two groups can be found in Tremblay-Gaudette, Gabriel. "Dessine-moi la télépathie: Body World de Dash Shaw. CRAS: dossier spécial.
} 
most archetypically in the word/picture question. A great deal of (semiotically-inclined) attention has been paid to the interaction of the formal constituents typical of comics (panels, page lay-out, the interaction of the tabular and the linear element, or word/picture relationships (e.g. Groensteen, Système; Groesteen, Système 2; Kannenberg Jr.) and to the way in which the (uneducated) eye can or should interpret the language of comics (e.g. Peeters 1991), but the visual co-textualization of language in comics remains an as yet largely uncharted territory. Visual cotextualization, as a process involved in the overall comprehension of many stories and sign systems, is of course not as medium specific a phenomenon as a relatively young academic discipline such as comics studies might prefer to work on. Examples of the connection between non-standard language and the comics form are legion, however. The Yellow Kid invariably talks the poor man's talk, the language of Krazy Kat and his frenemies is characterized by an intensive use of Ebonics, and Zippy the Pinhead boasts a decidedly underground voice. More recently, Charles Burns has stretched the connection between comics and nonstandard language to its functional limits in Johnny 23 (2010), a bootleg version of his own X'ed Out (2010) in which he has replaced the original English text with a text rendered in an (as yet) unidentified cryptographic alphabet. Although it is far from a medium specific process, visual cotextualization is a key element (one may even posit that it is the fundamental possibility condition) for the efficiency and creative concept of the above works. As an extension of the narrative creativity which comics' double nature is often said to stimulate, the possibility for the intelligibility of non-standard language through visual co-textualization opens up new narrative challenges and opportunities. Our analysis thus emphasizes and proceeds from the idea that understanding a language in a specific story rendered in a specific medium can be a creative act. Although the word-image problematic is of course informative with regard to the question of co-textualization, our exploration will require us to put concerns with comics as a medium between brackets.

If comics studies does not seem overly concerned with the question of language comprehension, scholarly treatises in the domain of education very much are. These studies almost always focus on what Rufus K. Marsh calls "the instructional use of comics" (777), however, often opting for very pragmatic, goal-oriented approaches that aim to measure the usefulness of comics for educational purposes (language comprehension with comics, not in comics as it were). Although the importance of co-text (and for that matter context too) in language transfer is often underlined, these studies do not ask the question as to how co-textualizing operations work. In contrast with comics theory, education studies (naturally) pays little to no attention to the question of medium or medium specificity. Their instrumental approach does not leave much room to consider the visual co-textualization of language from a creative point of view either. 
Both reading comprehension and cognition studies do ask the question as to how things work, but they do so from a reader-centered, empirical point of view, which, while very thorough and measured, ultimately does not completely allow us to grasp the phenomenon under scrutiny. The interest of this line of inquiry can be summed up as "how do readers understand and make use of information from a text?" (Carr 592), as such, while it describes the process which we will be dealing with, it does not habitually do so in either a comics (narrative) or a language context. Reading comprehension studies does allow us a more refined use of the concept of co-textualization, however. Co-textualization has been investigated as an important reading strategy for many decades and while its significance has never been fundamentally challenged, research shows that the phenomenon is far more complex and especially dynamic than one might suspect. Depending on the skill of the reader (reading skill, not language skill), the deployment of a given co-textualization strategy may be both extremely helpful and extremely detrimental to the overall reading process, for example (Carr; Norman). A number of interesting reading strategies with regard from language comprehension may be gleaned from the literature, including the use of comparison (synonymy), contrast (antonymy) and inference. These strategies help to streamline reading processes such as affective response and intertextual connection and as such further language comprehension on the level of representation, interpretation and extension (as when the co-text provides information that suggests positive or negative connotations of a term). On a meta-level, these elements can help readers create a reading hypothesis with regard to the purpose/intention of the author of a work.

The intentional question brings us to the cultural approach of the cotextualization of non-standard language in comics. It is true that if we have spoken of comics studies before, we have mainly focussed on the theoretical part of the scholarly spectrum. On the intersection of comics studies and cultural studies, however, essays that address non-standard language in comics do exist. They are, however, more interpretational in scope. In "How To Read Chico Bento: Brazilian Comics and National identity" (2011), Jennifer Manthei elaborates on how the Brazilian Caipira dialect used in Mauricio de Sousa's Chico Bento comics signals social class relationships that fit into the image of the nation as constructed by the Brazilian state apparatus of the military dictatorship (1964-1985). A strong focus on ideology and nationalistic sentiments can also be observed in "Captain Canuck, audience response, and the project of Canadian nationalism" (Dittmer and Larsen 2007), which reconstructs traces of the desire for "decentralized federalism" and of a hypothetical Canadian essence in the text and reception of the Captain Canuck comics. If ideology has proven to be a fruitful way of devoting analytical scholarly attention to non-standard language and national identity in comics, our 
project will come at these issues from a different angle, that of folklore (which, in contrast to ideology, is entirely rooted in the domain of culture, creation and performance and does not explicitate a top-down, abstract, comprehensive worldview).

In sum, our analytical exercise aims to rehabilitate the issue of linguistic comprehension as a site for narrative and cultural creation by paying attention to the way in which visual co-text can help the understanding of non-standard language in a fictional environment.

\section{Motel Galactic and Motel Galactic 2: Le Folklore Contre-Attaque}

\subsection{Plot Summary}

The plot of Motel Galactic is easily summarized. Pierre Bouchard 2.1.1., a classic antihero, who speaks to us from the year 2514, introduces the idiosyncrasies of the world in which he lives before a series of seemingly unrelated encounters leads him to the Motel Galactic, which was once the site for resuscitation experiments on a cryopreserved original human being, a citizen from Saguenay Lac-Saint-Jean who drowned in the lake while attempting to cross it on his ski-doo ${ }^{5}$. As Pierre 2.1.1. explains to the reader, his universe is primarily populated by version upon version of (modified) clones of biologically begotten humans (the 1.0 versions) and the discovery of such an original human constitutes a great scientific opportunity. Pierre finds out that he was cloned from the cryopreserved human and discovers his "Original" in a shabby room in the Motel Galactic only to notice that the latter was stripped of his brain by an assistant who had developed second thoughts about the ethical implications of the experiments he was taking part in. On his quest to retrieve the missing part, Pierre meets the doctor who led the experiments on the original Pierre and together they track down the assistant, secure the brain and revive Pierre 1.0. In the second book, a Star Wars pastiche which thematizes the question of Quebecitude more explicitly than the first volume, we find Pierre 2.1.1. and Pierre 1.0. toasting marshmallows on a campfire $^{6}$. The clone explains to his Original how space clown Guy Laliberté (a reference to the Quebecois founder of Cirque du Soleil, philanthropist and one-time astronaut, of course) conquered the universe and installed spatio-Joual as its lingua franca. Soon we see the brain-thieving

\footnotetext{
5 The cultural references here are of a double nature. On the one hand, there is the intertextual science-fiction reference to Michael Crichton's Jurassic Park and the Futurama television show, but on the other hand, death by drowning of (presumably very drunk) ski-doo drivers attempting to cross a frozen lake is an almost-yearly occurrence in Quebec.

6 In contrast with the first book, this campfire set-up does not translate into the preponderance of the first person voice-over technique throughout the rest of the story of Motel Galactic 2.
} 
assistant from the first volume pair up with Darte Brador, Guy Laliberté's defeated general. In exchange for his help in retaking control of the universe, the assistant asks Brador to eradicate Pierre 2.1.1., Pierre 1.0. and the doctor, but with the help of more Star Wars inspired characters, our (anti)heroes manage to ward off Brador's attacks. Eventually the crew meets the general and the assistant in battle at the Motel Galactic and emerges victorious, but not before having discovered that Darte Brador is actually the devil in disguise.

\subsection{Motel Galactic, Produit du Terroir}

The Motel Galactic series is first and foremost a regional product, "une science-fiction du terroir" in the words of the creators of the two books. Adopting a folklore approach to Quebecitude, the books rely on a constant and often anecdotal infusion of Quebecois values, traditions and customs into the story in order to build a network of signification, which, in conjunction with the overarching science fiction quest plot, produces a delectable effect of auto-irony. Thus, in his search to find Pierre 1.0.'s brain, Pierre 2.1.1. stumbles upon a planet populated by members of Quebec's bûcheron et draveur (lumberjack and raftman) culture. In the future, the lumberjacks still wear checkered shirts and gather around the fire to share fishing and hunting stories, only as their planet does not host any wildlife (or indeed nature, the entire surface of the planet being covered by an enormous wooden shack), their narratives cannot be rooted in real experience. Instead, their accounts are retellings of the adventures of their forebears and have grown into authentic tall tales over the course of many generations. The three-eyed purple fish that star in the stories of the bucherons then emphasize the gently caricatural nature of the way in which the lumberjack colony is depicted in Motel Galactic (and through that Quebec's collective fondness for the frontier life). Additionally, the mutated fish may be read as a meta-fictional comment about the story which Pierre, its first person narrator, its protagonist and presumably also the alter ego of the artist Pierre Bouchard, who draws the series, is telling us. Especially in the first volume, the preponderance of the first person voice-over technique bestows an "oral transmission by the campfire" effect on the reading experience.

Intertextual references constitute another notable strategy to make Motel Galactic come alive as a Quebecois sci-fi tall tale. Both references to the collective cultural Quebecois memory (including cult soap opera characters and stories that have marked the collective Quebecois imagination, as well as contemporary personalities such as Régis Labeaume, the current mayor of Quebec city, and the late Andrée Boucher, Quebec city's former mayor) and associations with contemporary Quebecois Web culture (in the first book Pierre visits a planet where he encounters 
Youtube "phenomenon" and fellow space traveller Esbark le robot") are used to this end. The science fiction conventions that mark the quest plot of the books are also intertextually emphasized. The subtitle of the second volume - "Le folklore contre-attaque" - is of course a reference to George Lucas's second Star Wars film The Empire Strikes Back. By replacing "Empire" with "folklore", not only does this title emphasize the crossgeneric quality of the series, it also reminds us of the distinction between ideology and folklore (and of our preference for the latter concept as an analytical frame). The books' rejection of ideology is reflected in the editorial line of their publisher Les Éditions Pow Pow. This young independent publishing house (2010) explicitly profiles itself as a publisher of Quebecois comics, both with regard to language and theme. As editor Luc Bossé explains, however, the usage of Quebecois language is not a political, but rather a creative and strategic issue for Pow Pow: "Il m'est déjà arrivé de demander à un auteur potentiel de changer le niveau de langage de ses dialogues. Le texte original avait un "français international" et son livre était destiné au marché Quebecois. En ramenant le texte à un français parlé plus Quebecois, je voulais que le lecteur s'identifie d'avantage aux personnages." (Private correspondence). This approach of course contrasts quite starkly with the reasons for using Quebecois in comics during the Printemps de la bande dessinée québécoise of the 1960s.

\section{Functional and Creative Visual Co-textualization in Motel Galactic}

Motel Galactic is riddled with Quebecois vocabulary and idioms (including expletives), pronunciation, grammar and syntax. The reader is confronted with such colourful and mysterious words, phrases, and sentence structures as, "Wo! Wo! Wo! Les Moteurs!" for "Du calme!", "Calvâsse que tu sens le y'âb." for "Tu sens très mauvais.", "M'a te montrer quetchose." for "Je vais te montrer quelque chose." and "Quessé ça? T'es qui toé?!" for "Qu'est-ce que c'est que cela? Qui es-tu?". More accessible instances that showcase grammatical particularities include "Ça va-tu me coûter cher?" for "Est-ce que ça va me coûter cher?" and "T"es-tu correct, Kaylynne?" for "Est-ce que tu vas bien, Kaylynne?" which indicate how "tu" may be added to a sentence as a question particle in Quebecois. Although there is some variety in register in the series - the first person narratorial voice-over contains less colloquial elements than the dialogues

\footnotetext{
7 This intermedial reference is an inside joke aimed at a webculturally savvy subsection of the Quebecois readership. Esbark is the main character in an underground cult series of (shoddily) animated short movies. The movies are drawn in a primitive, childlike manner and are accompanied by a soft-spoken expository voice-over that both describes the action and renders the dialogues. These elements in combination with the completely silly plot of each episode (which is reflected in titles such as Esbark dans l'arbre avec une porte or Esbark sur la planite des pas rapports) make the adventures of Esbark into an absurd parody of a children's series.
} 
do, for example, select characters speak international French and one even speaks Yoda-Joual - the language used in the books is overwhelmingly informal, popular and plastic/figurative, as befits a folk tale. In his article "Français international, français québécois ou Joual: quelle langue parlent donc les Québécois?" Claude Verreault warns exactly against such a folkloristic approach to the Quebecois sociolect. The author admonishes the reader that "une telle réduction [a reduction of the French spoken in Quebec to its use in informal and popular situations] n'a pu que contribuer à véhiculer une image essentiellement folklorique et caricaturale non seulement du français du Québec, mais aussi de la société québécoise tout entière" (128). Of course Desharnais and Bouchard bypass Verreault's criticism by fully embracing the folkloristic element in their books and escalating it to the level of the tall tale. The ironic dimension of their narrative allows them to handle stereotypes in a non-reductive manner. In fact, the books turn a stereotypical rendition of the sociolect into a productive device on the level of not only the image of the territory, its language and culture, but also on the level of the narrative and of language transferral ${ }^{8}$.

It is possible to distinguish two types of visual co-textualization operations that facilitate the comprehension of Quebecois in Motel Galactic: a functional type and a creative type. Both types presuppose linguistic comprehension and both are functional in terms of reading comprehension, but the creative type allows the exercise in linguistic and reading comprehension to culminate in narrative meaning. In other words, the creative (or narrative) type exploits the relative incomprehensibility of the non-standard language so that it may fulfill a narrative function. In what follows we will focus on two such narrative functions: characterization and foreshadowing, but first let us have a look at visual cotextualization operations of a functional nature.

Most functional instances of visual co-textualization (or rather sites where the reader may undertake a visual co-textualization operation) are related to lexical matters and many of them rely on the process of inference-making, as when the deflated facial expression of the protagonist of the series indicates that "Ouin ben...je pense que je commence à avoir

\footnotetext{
8 It could be tempting to surmise that the sketchy, imprecise and unpolished style characteristic of Pierre Bouchard's art is a direct visual counterpart of the scraggly and colloquial language used by the characters in the books. This might lead one to posit a connection between the use of Joual (and dialect in general) in comics and drawing style. However, this hypothesis does not hold up if we consider the general production of bande dessinée québécoise, as we can observe that the presence of Joual in comics dialogues is not systematically accompanied by an imprecise drawing style; on the contrary, comics such as L'ostie d'chat by Zviane and Iris or Vil et miserable by Samuel Cantin, which do use Joual, deploy a style reminiscent of the European Ligne claire.
} 
un peu la chienne..." (Motel Galactic, 61) does not refer to a happy sentiment (Image 2).

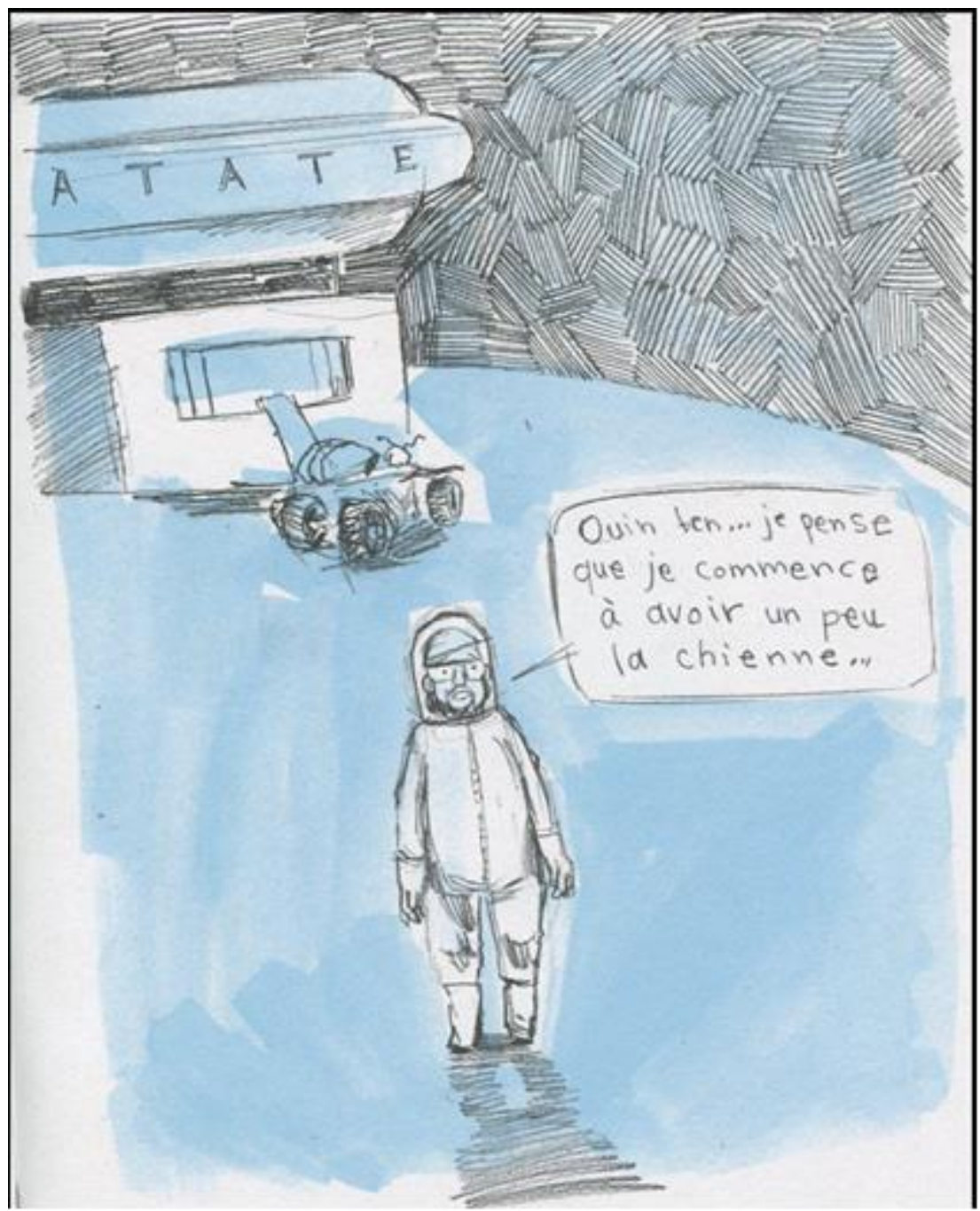

Image 2

Whether "avoir la chienne", indicates fear or impatient irritation is not entirely clear from the immediate visual co-text, however, and this confusion is further intensified by the preceding verbal and narrative cotext. After all, the sentence in question is uttered at a time when Pierre 2.1.1. once again finds himself thwarted on his road to the Motel Galactic (he loses the assistant to a freak meteor accident right at the moment when the latter speaks the ominous words "Quoi...C'est toi que...qu'on a...[...]Noooooon!" (Motel Galactic, 60)). In addition and in conjunction with the narrative co-text, the word group "penser de commencer à avoir [quelque chose]" which precedes the Quebecois phrase may imply irritation and impatience more readily than fear depending on the background and reading experience of the reader. Two important observations can be 
gleaned from this example. The first is that attempts at visual cotextualization need not necessarily lead to complete or even functional comprehension. The phenomenon (and the accompanying reading strategy) is best considered on a spectrum. Secondly, it is necessary to emphasize the importance of verbal co-textualization even in verbal-visual art forms. Especially in the first volume and with regard to linguistic comprehension, many co-textualization operations rely on information which can be found in the text rather than in the drawings, which function much like extensions?. The presence of pictures in word-picture works should thus not be taken to mean that visual co-textualization is a given in these works (insofar as we are considering word-picture comics, this remark also applies to the comics medium of course). Other instances of functional visual co-textualization may rely on the notion of grammatextuality in combination with a comparative/contrastive strategy. Especially in the case of exclaimed expletives ("Calvâsse!", "Tabarslak!") bold, emphatic, a-typical lettering often makes it immediately clear how they should be interpreted. At times these highly idiomatic elements are further rendered intelligible by grace of comics conventions pertaining to the shape of speech balloons for example. Because the informality of nonstandard language use is readily associated with frankness, affective expression and possibly coarseness, the grammatext and the comics conventions which signal swearwords at once also signal the term's adherence to non-standard language. In the same vein, the informal character of the expressive hand lettering that is the standard in Motel Galactic may be said to aid linguistic and reading comprehension for the text as a whole. On certain pages, the initial penciling of the letters (as with the drawings) even shines through, giving the books an intriguing air of nonchalant possibility.

It is in the second book that our inquiry into the creative type of visual co-textualization in comics reaches its apex. As mentioned, Motel Galactic 2: Le folklore contre-attaque differs from its predecessor in that it contains far less text and thematizes the Quebecois language more overtly. This change arguably manifests because Desharnais and Bouchard make use of the doubleness of the language of comics in a more refined way in the second volume. In terms of visual co-textualization, we note first and foremost that the increased amount of dialogues captured in text balloons that are tethered to characters greatly adds to the overall potential for pragmatic cotextualization in the book. Regardless of further visual co-textualization (creative or functional), seeing the language in use in a dialogic rather than a monologic (the first-person narrative of book one) mode makes for a

\footnotetext{
${ }^{9}$ As we have mentioned, the anecdote and the collective cultural intertext, although not crucial to the plot in Motel Galactic, are important elements to the story. The fact that this network of signification is expressed primarily in visual extensions to a verbal master narrative is fascinating to say the least considering both the relative marginality of Quebec and of pictures within their respective systems.
} 
reading experience richer in grounds for inferential, contrastive and comparative operations. We see a particularly successful instance of pragmatic co-textualization at work when Pierre 1.0. tries to buy snacks from a curious stand at a real life space derby (Image 3 ).

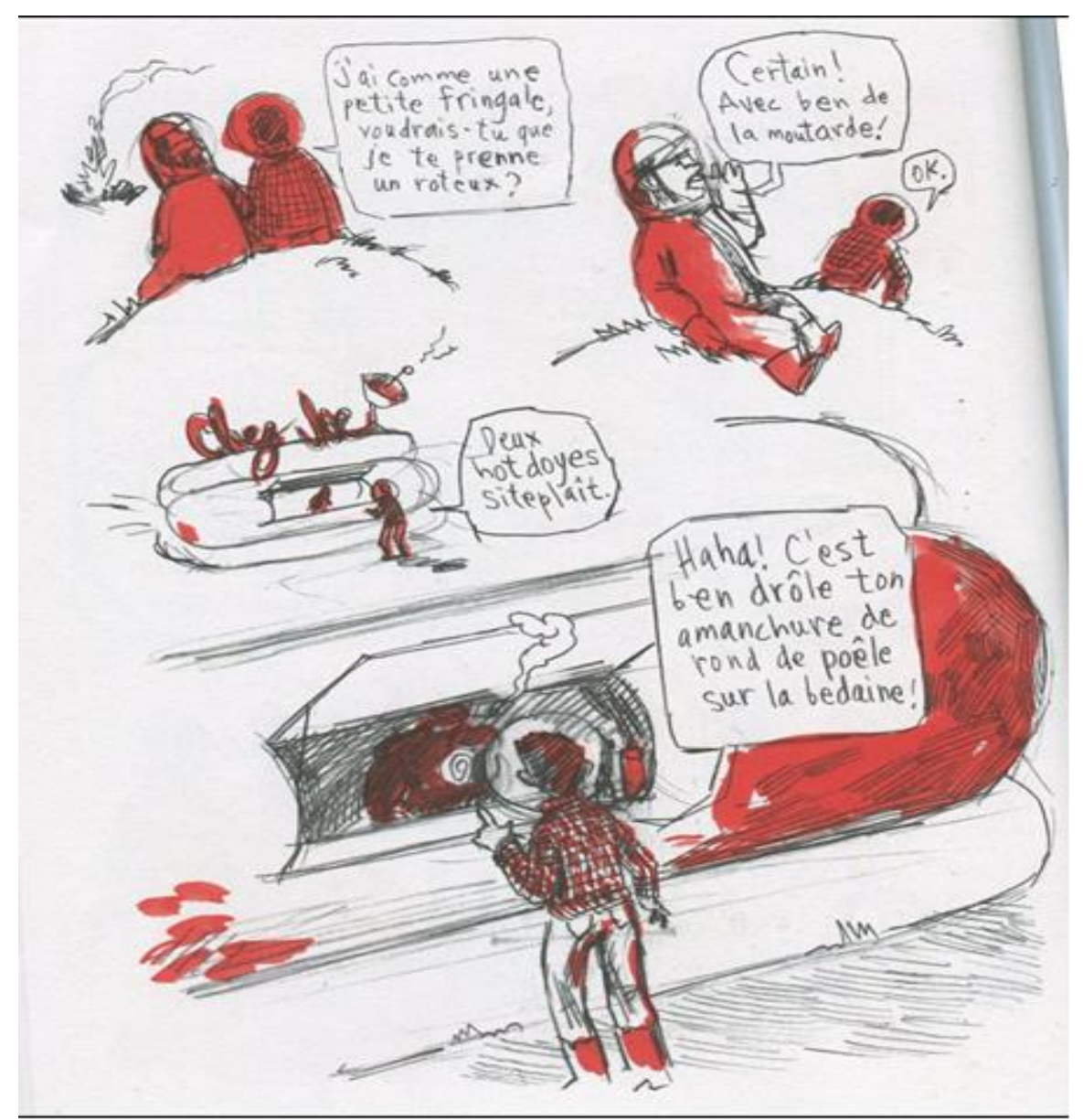

Image 3

Pierre 1.0. proposes to get the food - "J'ai comme une petite fringale, voudrais-tu que je te prenne un roteux?" (Motel Galactic 2, 40) - to which his clone replies quite enthusiastically: "Certain! Avec ben de la moutarde!" (Desharnais and Bouchard, 40). In the next borderless panel, Pierre 2.1.1. is shown asking the worker in the hotdog stand "Deux hotdoyes siteplait." (Desharnais and Bouchard, 40). In this example, multiple co-textualization operations allow the reader to reach a maximal level of comprehension on both the level of non-standard vocabulary (roteux) and non-standard pronunciation (hotdoyes). These operations involve both visual and verbal 
reading strategies and rely on the comics-specific function of tabularity ${ }^{10}$. The most compelling co-textualization operation in the above example arguably relies on verbal synonymy. The meaning of the word "roteux" in Pierre 1.0's offer becomes near-unambiguously clear because it is repeated in the word "hotdoyes" in his corresponding order at the hot-dog stand. This meaning is foreshadowed by an extension, namely Pierre 2.1.1.'s request to add lots of mustard to his "roteux". Finally, the presence of a hot-dog stand in the shape of a hot-dog allows readers to make inferences that not only drive home the meaning of the phonologically spelled "hotdoyes", but also of that of "roteux". Because all of these processes operate in a tabular regime as well as in a sequential one, it is impossible to conceive of them as exclusively occurring in the order in which we have just placed them. A reader could for example build a functional reading hypothesis based on a glimpse of the hot-dog stand in conjunction with the extension and then see that hypothesis confirmed through the process of synonymy. In addition to this functional aspect, Pierre and Pierre's hotdogs also fulfill a narrative function in the story of Motel Galactic, one that is based on the retroactive connection between verbal and visual cotextualization. As a way of providing a background for this exercise, let us first have a look at a case of non-pragmatic creative visual co-textualization that fulfills a characterization function.

As Pierre 2.1.1. recounts the origin of the linguistic hegemony of spatioJoual, he describes how Guy Laliberté at one point in his space reign was compelled to create a spectacularly forceful and charismatic right hand. Brought forth from an unholy union of Lalibertés twisted fantasies and Quebec's collective imagination, Darte Brador is "un homme qui est aussi autoritaire et violent que la mère de la petite Aurore/Aussi charismatique que Jean-Paul Belleau/Et aussi près de ses cennes que Séraphin" (Motel Galactic 2, 19) (Image 4).

\footnotetext{
${ }^{10}$ A concept introduced to comics studies by Pierre Fresnault-Deruelle (1976), tabularity signifies the spatial, atemporal arrangement of graphic elements on a surface (usually the page) in contrast to a linear, sequential approach thereof.
} 




Image 4

Under each text column introducing these unsympathetic characters of fictional works from Quebec, a number of icons appear. Soap and an electrical burner for the (step)mother of little Aurore, eye-catching glasses and a moustache for Jean-Paul Belleau and a pipe and a money sack for Séraphin. In terms of the visual co-textualization of language, the money sack allows us to infer the meaning of the idiom "près de ses cennes" and thereby visually underlines the textual indication that Darte Brador is a greedy man. The obscurity of this idiom (and the corresponding need for the co-textualization) allows an independent intensification (a repetition) of Brador's characterization that is interestingly not applicable to the other icons. The soap and the electrical burner refer to a real-life child-abuse story from Quebec which has been fictionalized multiple times and in which Aurore's stepmother terrorizes and tortures her ward by, amongst other things, burning the child's hands on the stove top and making her eat 
soap. The glasses and the moustache are trademark accessories of chronic ladies man Jean-Paul Belleau, a character in the Quebecois telenovella Des dames de coeur (1986-1989). Finally, Séraphin (whose last name is later confirmed to be Poudrier) is a miserly Quebecois character who is habitually depicted as smoking a pipe ${ }^{11}$. These visual elements rely on the pars pro toto principle as a way of engaging with the qualities listed in the text (note that this effect may be lost on foreign readers that are unfamiliar with the intertextual references) and their co-textualizing power (with regard to said intertextual references) is minimal, leaving them without the capacity to express characterization in a separate meaning-making operation. As pars pro toto attributes, they come into their own as characterization intensifiers when we see Darte Brador outfitted with a pipe (but not a money sack), a moustache, glasses and a costume featuring the image of an electrical burner coil on the next page of the book. Additionally, in their capacity as pars pro toto, they foreground the amalgamous nature of the character. Darte Brador also adopts "Viande à Chien!" the idiolectic expletive phrase coined by Séraphin as his personal curseword, which brings us back to the creative power of hot-dogs in Motel Galactic 2.

The incremental fashion in which readers may come to comprehend the meaning of "roteux" foreshadows the process of discovery and of the development of suspense with regard to the identity of the antagonist in the story. Darte Brador is eventually identified by Pierre 2.1.1. based on the expletive phrase which he is said to have shouted at Pierre 1.0. in his role as a partially hidden hot-dog vendor. On the verge of idiom and idiolect, "Viande à Chien!" is introduced as the "juron de Séraphin" at the moment of the metaphorical unmasking of Pierre and Pierre's attacker and this textual specification combines with a previous grammatextual cotextualization of the phrase as a curse phrase to finally render it comprehensible within the story. The culmination of this process of idiomatic comprehension for the reader coincides with the point in the story in which Pierre and Pierre once again become actively and consciously involved in an epic struggle. Thus, the (non-Quebecois) reader and the main characters in the book simultaneously experience an $A b a$ Erlebnis.

\section{Conclusion}

\footnotetext{
11 Séraphin Poudrier is the main character of Claude-Henri Grignon's novel Un homme et son péché, first published in 1933. The novel was adaptated into a radio soap opera, a comic book, a television series and no less than three movies. Séraphin is a greedy cheapskate who lets his lovely wife Donalda die of a banal fever rather than spend a dollar on a doctor's visit; in popular Quebecois parlance "être un Séraphin" means "being excessively cheap and frugal". In Quebec's mythology, Séraphin Poudrier is the archetypal villain.
} 
In the middle of the third instalment of the Motel Galactic series, Comme dans le temps, Pierre 2.1.1. and Pierre 1.0. travel back in time and end up meeting Voltaire and Louis XIV. The encounter, however brief, is symptomatic of the doubleness of the relationship between Quebec and France. Voltaire shows a clear disdain for Joual but Louis XIV is seduced by its musicality: "Il y a quelque chose d'extraordinairement authentique dans cette "parlure". Quelque chose qui donne l'impression d'être très loin, mais aussi très proche..." (Motel Galactic 3, 70) (Image 5).

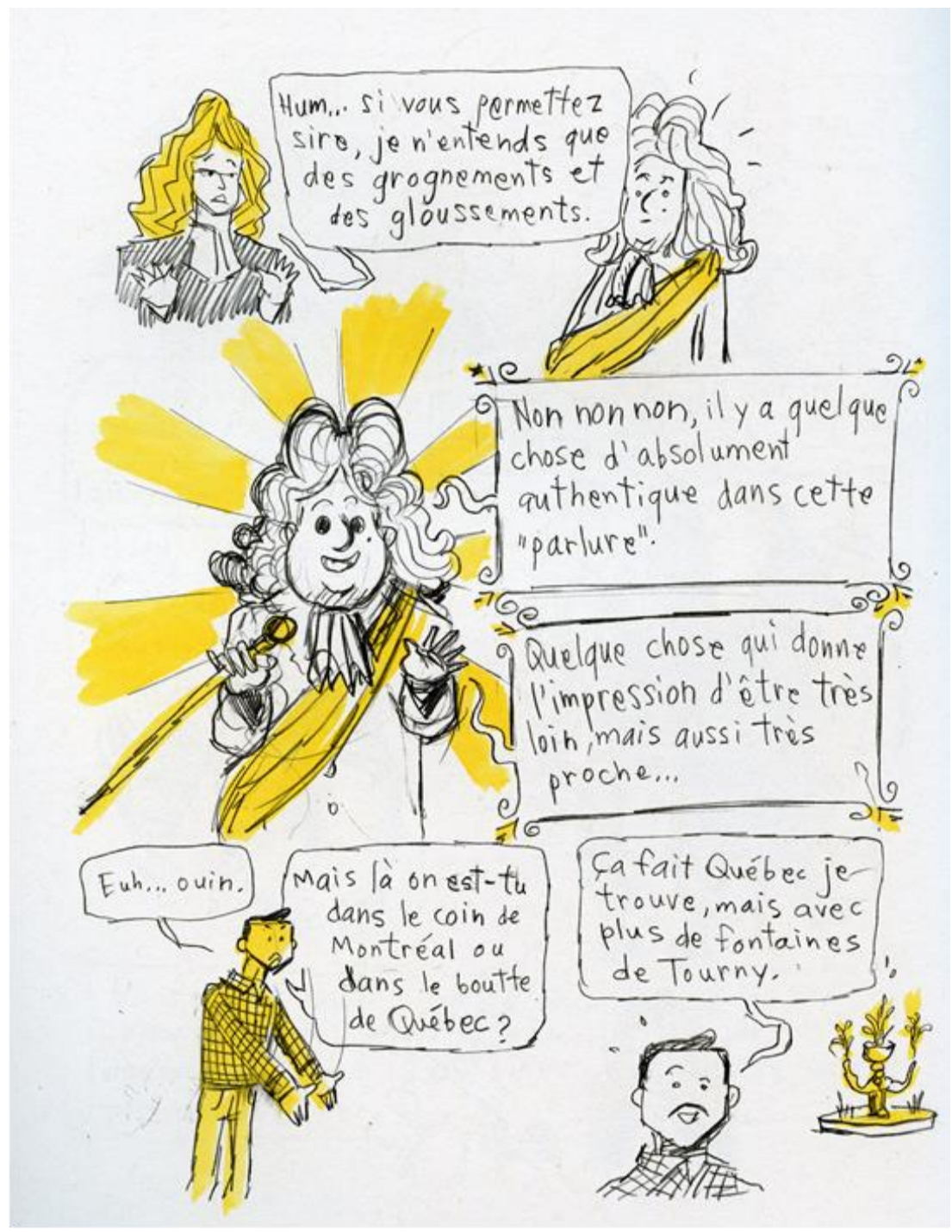

Image 5

This encapsulates the layered appreciation of the Quebecois language and accent by French people which often comes down to a mixture of fascination and repulsion. On the other hand, when Louis XIV tries to speak à la Québécoise, Pierre 2.1.1. tells him "Euh, non, sérieux, essaye pas d'imiter l'accent, j'ai jamais entendu un Français qui l'avait 
comme du monde." (71) (Image 6), indicating an emancipation of the Quebecois clone vis-à-vis his now very distant "cousin": not only does Pierre 2.1.1. defend the specificity of his accent by asking Louis XIV not to try his hand at it because he does not have what it takes, he also gives orders to a king, implying a turning of the hierarchical tables.

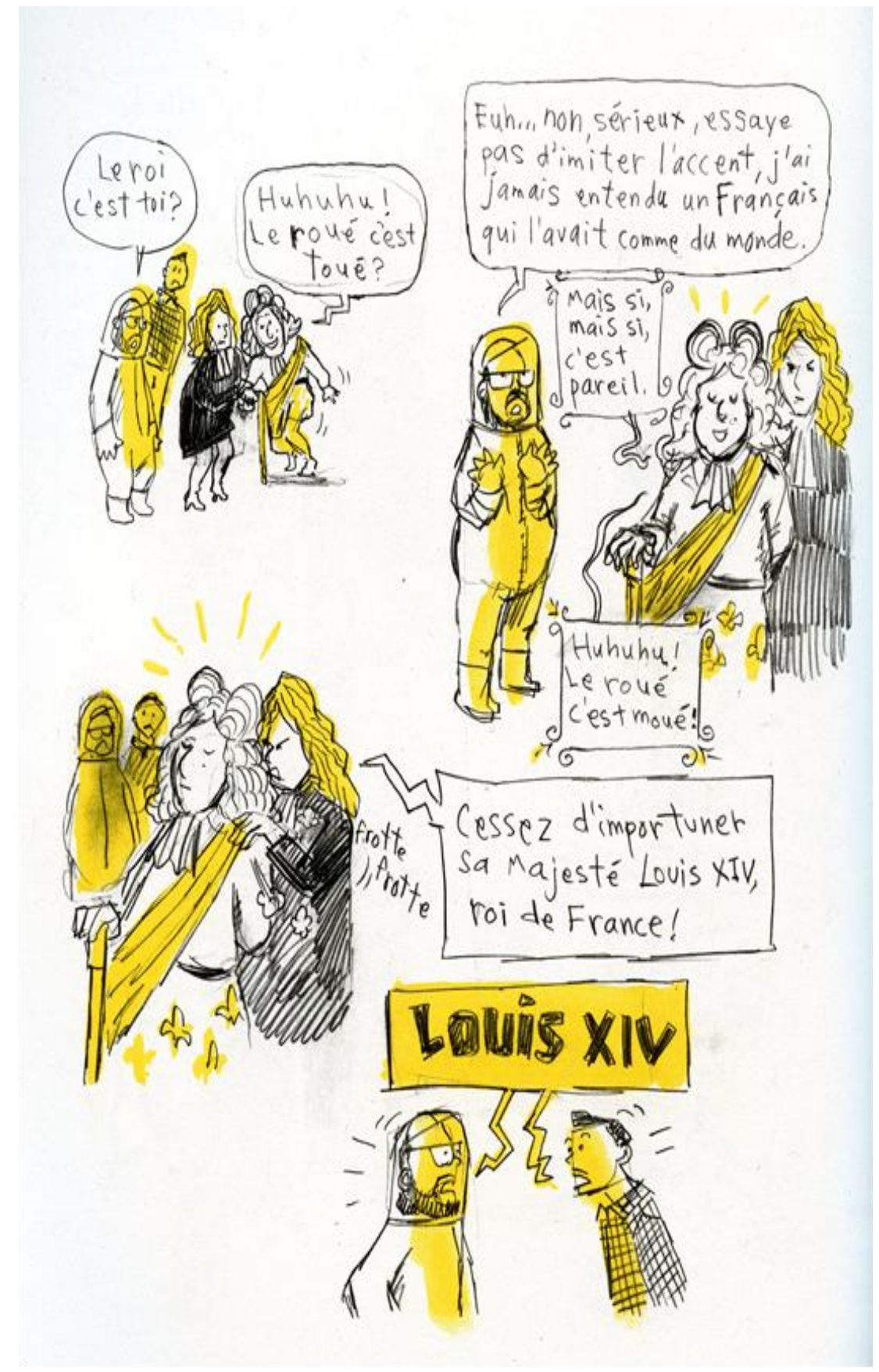

Image 6 
This brief exchange is perhaps the most overt affirmation of Quebecois pride in an otherwise very auto-ironic and indirectly (performatively) affirming series. It is also the most overt sign of the affection of the artists for (spatio-)Joual and of the validity which they accord to the language, as Louis XIV comments on the authenticity of Pierre and Pierre's "parlure", noticing the fact that it sounds both close and near, both the same and different as their "true" French.

It appears that these days the French attitude towards Quebec swings more to the fascination side of the spectrum, certainly in the realm of comics. As mentioned earlier, Jimmy Beaulieu and Michel Rabagliati have made forays into the French marketplace, and young artists such as Pascal Girard (Conventum) and the duo Zviane and Iris (L'ostie d'chat) are also published by Delcourt in the Shampooing imprint. Interestingly, L'ostie d'chat started as an online blog aimed at a Quebecois readership, but when it was picked up by Shampooing, its Quebecois particularities were warmly welcomed, as Zviane explains: "Quand [Iris et moi] avons publié L'ostie d'Chat chez un éditeur français, nous avions demandé à l'éditeur Lewis Trondheim s'il voulait qu'on change des choses au plan de la langue, ou que l'on inclus un lexique. Il nous a répondu "Absolument pas. C'est du québécois, point."" (Private correspondence)

Even though Quebecois comics are increasingly read abroad, the case study which we have investigated in this text is, as mentioned, aimed at a Quebecois readership. We found it both revealing and astonishing that this act of performative folkloric storytelling, which relies strongly on Joual, contained so many co-textualizing opportunities. While this might indicate that (visual) co-textualization is an important part of storytelling and reading comprehension regardless of linguistic intelligibility, we hypothesize that the fact that Joual is a non-standard language is important in this regard. As the increasing presence of co-textualization in the second volume suggests in conjunction with the more extensive thematization of language in that book, the process might be a way to evoke the ex-centric specificity (reflected in for example a lack of linguistically institutionalized footing) of a language by appealing to the idea of its perceived unintelligibility. By using Joual in this fashion (in addition to foregrounding folkloric elements of the Quebecois culture), Motel Galactic becomes an authentic demonstration of the uniqueness of Quebec's (cultural) identity without having to resort to the overt thematization of the political issues that are usually associated with the province. Co-textualization then becomes a macro-narrative creative device, one which both contributes to the illumination of Quebecois folklore and culture and to the learning of Joual.

The aim of this paper was to determine how the potential for hybridity typical of the comics medium might foster opportunities for the 
comprehension of dialectical language. As we have shown, visual cotextualization constitutes a productive strategy for comics readers to decipher the meaning of words with which they are not familiar. While cotextualization can certainly aid linguistic and reading comprehension, we have also found that it has limitations in this regard. Co-textualizing strategies might lead a reader to misinterpret an unknown term and the pronunciation of new words (and in some cases sounds) cannot easily be inferred through co-textualization. In the case of languages that are not institutionalized in writing, such as Joual, this is a particular hindrance. 


\section{Bibliography}

Baetens, Jan. "Words and Images." Cambridge Companion to Comics. Cambridge: Cambridge University Press, 2016 (forthcoming). Print.

Carpentier, André (ed.) La barre du jour, n. 46-49, «La Bande Dessinée Kébécoise » (Winter 1975). Print.

Carr, Thomas H. "Research on Reading: Meaning, Context Effects, and Comprehension." Journal of Experimental Psychology 7.3 (1981): 592603. Print.

Couperie, Pierre. "Antécédents et définition de la bande dessinée." Comics: l'art de la bande dessinée. Eds. Walter Herdeg and David Pascal. Zürich: The Graphics Press, 1972. 9-13. Print.

Desharnais, Francis and Pierre Bouchard. Motel Galactic 3: Le bon vieux temps. Montreal: Les Éditions Pow Pow, 2013. Print.

- Motel Galactic 2: Le folklore contre-attaque. Montreal: Les Éditions Pow Pow, 2012. Print. . Motel Galactic. Montreal: Les Éditions Pow Pow, 2011. Print.

Groensteen, Thierry. Système de la bande dessinée 2: Bande dessinée et narration. Paris: PUF, 2011. Print. Système de la bande dessinée. Paris: PUF, 1999. Print.

Hatfield, Charles. Alternative Comics, An Emerging Literature. Jackson: University of Mississippi Press, 2004. Print.

Kannenberg, Gene Jr. "The Comics of Chris Ware: Text, Image, and Visual Narrative Strategies." The Language of Comics: Word and Image. Eds. Robin Varnum and Christina T. Gibbons. Jackson: University Press of Mississippi, 2001. 174-197. Print.

Lapacherie, J.G. "De la grammatextualité." Poétique. 5.9 (1984): 283-294. Print.

Lemay, Sylvain. Le "Printemps" de la bande dessinée québécoise (1968-1975). PhD dissertation. Montréal: Université du Québec à Montréal, 2010. Print.

Marion, Philippe. Traces en cases: travail graphique, figuration narrative, et participation du lecteur. Louvain-La-Neuve: Academia, 1993. Print.

Marsh, Rufus K. "Teaching French with the Comics." The French Review 51.6 (1978): 777-785. Print.

McCloud, Scott. Understanding Comics. The Invisible Art. New York: Harper Perrenial, 1993. Print.

Morgan, Harry. Principes de littératures dessinées. Paris: L'an 2, 2003. Print.

Norman, Rebecca R. "Reading the Graphics: What is the Relationship between Graphical Reading Processes and Student Comprehension?" Reading and Writing 25.3 (2012): 739-774. Print.

Peeters, Benoit. Lire la bande dessinée. Paris: Flammarion, 1998. Print.

1991. Print. Case, planche, récit: comment lire une bande dessinée. Tournai: Casterman,

Pernin, George. Un monde étrange: la bande dessinée. Paris: Clédor, 1974. Print. 
Pylyser, Charlotte. An Archaeology of the Flemish Graphic Novel. Diss. Catholic University of Leuven, 2014. Print.

Rambaud, Pierre, "BD", La Barre du jour: La bande dessinée kébécoise. Winter 1975, n. 46-47-48-49 : 63-72 pages. Print.

"La dynamique des langues en quelques chiffres: tableaux." Secrétariat à la politique linguistique Québec. n.d. Gouvernement du Québec. Web. 15 Dec. 2014.

Smolderen, Thierry. "On Labels, Loops and Bubbles: Solving the Historical Puzzle of the Speech Balloon." Comic Art Magazine Summer 2006: 59-76. Print.

Tremblay-Gaudette, Gabriel. "Dessine-moi la télépathie: Body World de Dash Shaw. CRAS: dossier spécial (2014). Web.

."Tensions, prétensions et galvaudages: gains et écueils du roman graphique comme stratégie du cheval de Troie en Amérique du Nord." Kinephanos 2.1 (2011): 31-50. Web.

Varnum, Robin, and Christina T. Gibbons. "Introduction." The Language of Comics: Word and Image. Eds. Robin Varnum and Christina T. Gibbons. Jackson: University Press of Mississippi, 2001. Print.

Verreault, Claude. "Français international, français québécois ou joual: quelle langue parlent donc les Québécois?" Culture française d'Amérique. Ed. Andrée Fortin. Laval: Les Presses de l'Université Laval, 2000. 119-131. Print.

Véronneau, Jean. "Introduction à une lecture de la bande dessinée québécoise, 1904-1910". Stratégie 1976: 59-75. Print.

Viau, Michel. "Grande presse et petits bonshommes. La naissance de la BDQ." Formule un, bears + beer. Ed. Jimmy Beaulieu. Montreal: Mécanique générale, 2007. 13-51. Print. 